\title{
Pastor Jacobsen i Skærbæk og de kirkelige Myndigheder
}

ved M. Mackeprang

Da jeg for nogle Aar siden hjalp det af min gamle Institution Nationalmuseet udgivne Storværk „Danmarks Kirker", hvis nordslesvigske Bind jo nu er begyndt at udkomme, med at gennemgaa de kirkelige Arkivalier, og vi var komne til Tørninglen Provsti, forbeholdt jeg mig Lægget om Skærbæk Sogn. Det var dog ikke saa meget for Kirkens Skyld — om den var der heller ikke store Sager - som fordi jeg ventede her at kunne finde noget om den $i$ sin Tid saa omtalte, nu vel af de fleste glemte Pastor Jacobsen, der søgte at gøre den før saa gode danske By Skærbæk til et Fortyskningscentrum. Og i saa Henseende blev mine Forventninger da heller ikke skuffet. Efter Sagens Natur gav Akterne dog ingen nye Oplysninger om hans forskellige berømmelige Foretagender "Rederiet uden Skibe“, "Badestedet uden Vand“ (Lakolk), „Banken uden Penge“ og „Tegværket uden Ler“, som han selv galgenhumoristisk udtrykte sig. Herom og da navnlig om den af ham 1889 oprettede Bank, der skulde danne den okonomiske Basis for det hele, henvises til $\mathrm{H}$. P. Hanssens Redegørelse for „Köllerpolitiken“ i S. Aarb. 1907, S. $324 \mathrm{ff}$. Det nye, Akterne bragte, drejer sig udelukkende om hans Virksomhed som Præst og hans Personlighed. Nogen ubegavet Mand har han ikke været; tværtimod var han fuld af Idéer. Men han var grænseløs letsindig, for ikke at sige samvittighedsløs. Naar hertil kommer, at han aabenbart har været behæftet med forskellige andre menneskelige Skrøbeligheder, maa det jo nok siges, at han egnede sig grumme lidt til at være 
Præst og da allermindst i Nordslesvig, endsige da i et Sogn som Skærbæk, hvis Fører da ubestridt var en Mand som P. Timmermann "Skærbæks danske Konge“ som Pastor Jacobsen kalder ham, der baade var Medlem af de Kirkeældste og Formand for den danske Sparekasse, en slem Konkurrent for Præstens Kreditbank. Om P. T. jfr. f. ø. H. Lausten-Thomsen og Nic. Svendsen: „Haabets Mænd“ (1923) S. 233 f., hvor han med rette karakteriseres som „en af de smukkeste Bondetyper, Vestslesvig har fostret".

Af en Skrivelse fra Konsistoriet i Kiel til Provsten, Provst Gottfriedsen i Nustrup, af d. 29. Jan. 1894 fremgaar, at „man“ (d. v. s. Pastor Jacobsen) søgte at faa Timmermann afskediget som Kirkeældste, fordi han „begunstigede og befordrede den grundtvigianske Agitation".

Der skete dog intet, og allerede d. 28. Febr. meddeler Konsistoriet Provsten, at det har opgivet at sende en Kommission til Skærbæk for "an Ort und Stelle“, at undersøge Timmermanns Sag og henskyder Sagen til Provstiudvalget. At han i 1899 medvirker ved Oprettelsen af Frimenigheden i Skærbæk, („Haabets Mænd" S. 236) kunde jo dog nok tyde paa, at hans Tilbøjelighed gik noget i den Retning. Men $\mathrm{i}$ hvert Fald foreløbig medforte dette ikke hans Udtræden af Statskirken, thi endnu 1903 er han Kirkeældste og Medlem af Provstisynoden.

Det var dog ikke blot Timmermann, men ogsaa og i langt højere Grad Pastor Jacobsen, der voldte Konsistoriet Kvaler. I den ovennævnte Skrivelse af 29. Jan. anmodede det nemlig Provsten om at fremskaffe "bestemte Kendsgerninger", der kunde begrunde den mod Præsten rejste Bebrejdelse (Vorwurf), at hans politiske Virksomhed stred mod hans gejstlige Embede. Provstens Svar herpaa kender jeg ikke, men at det just ikke er faldet ud til Pastor Jacobsens Fordel, synes at fremgaa af, at en Konsistorialassessor d. 8. Nov. 1894 meddeler Provsten, at han - vist efter Ordre fra Regeringen i Slesvig - skal rejse til Skærbæk for at undersøge Præstens Forhold, i hvilken Undersøgelse Provsten skal deltage som Formand for Provstiudvalget. At Forholdet mellem Præst og Menighed længe har 
været saa slet som muligt, viser en ved Sagen liggende Afskrift af en dansk Skrivelse fra de Kirkeældste af 25. Nov. s. A. til Generalsuperintendent Dr. Kaftan, i hvilken det hedder, at Præstens Opførsel allerede i flere Aar har vakt Anstød i Menigheden. Kirkebesøget gaar tilbage, „Bornholmere“ og Baptister breder sig, Tanken om en Frimenighed dukker op, og „Drikkeriet tager mere og mere til", hvorfor de beder om, at han maa blive „forflyttet til en ny Virkekreds, hvor han kunde virke til mere Velsignelse end her". Misstemningen mod ham har aabenbart i dette Tilfælde nærmest beroet paa hans Hang til de vaade Varer. Man mindes uvilkaarlig Slutningen af en tysk Avis' Referat af hans Baaltale ved Lakolk i 1900 — „og Glassene klang" - (S. Aarb. 1907 S. 327). I en Skrivelse fra Konsistoriet til ham af 12. Dec. 1894 udtaler dette nemlig, at selvom det efter de foreliggende Vidneudsagn maa anse de mod ham rejste Beskyldninger for Drukkenskab ved en bestemt Lejlighed for gendrevne, staar det dog fast, at han den paagældende Aften fra 8 til 12 er gaaet fra den ene Kro til den anden, har drukket „Grog og Øl“ med Gæsterne, og henledt Opmærksomheden paa sig. En saadan Færd var uforenelig med hans Stilling som Præst „tilmed da det var sket paa en Markedsdag“. Ovenikøbet havde Kaftan jo paa sin sidste Bispevisitats paalagt ham Forsigtighed baade af Hensyn til hans Stilling og hans Modstandere, der holdt vaagent $\varnothing_{\text {je med }}$ ham ${ }^{1}$ ) og endda havde anmodet Konsistoriet om at faa ham forflyttet (jvfr. ovenf.)

Dette havde man dog set bort fra, men man lægger ham stærkt paa Sinde for Fremtiden bedre at opfylde sin stilling som „Kirkens Tjener“, ja truer ham ligefrem med en Disciplinærundersøgelse, hvis han ikke skikker sig. Til Gengæld lover det, hvis han ønsker det, at staa ham bi mod Amtsforstanderen

1) Dette fremgaar bl. a. af en Notits i ,Flensborg Avise (1895 22/5.) om en Brudevielse, hvor Præsten havde ladet vente paa sig, og da han endelig kom, var ude af Stand til at holde en Tale. Pastor J. sender det paagældende $\mathrm{Nr}$. af Bladet til Provsten, der maa have ladet det gaa videre til Konsistoriet, da dette 1 . Juli moddeler ham, at det har anmodet Statsadvokaten i Flensborg om at rejse Sag mod den ansvarshavende Redakt $ø r$ Nis Petersen. Historiens videre Forløb kender jeg ikke. 
cg Landraad Mauwe i Haderslev. Dette lyder noget mystisk, da Konsistoriet, omend ikke formelt saa reelt var en Regeringsinstitution, som regelmæssig fulgte den Vind, der blæste fra "den røde Bygning" paa Gottorp, og Pastor Jacobsen allerede dengang var Næstformand i „Den tyske Forening“. Med rette karakteriserede Kaftan, der ikke yndede „Foreningen“, i sine Erindringer ham som "mere Politiker end Pastor “, ${ }^{2}$ ) og at hans nærmeste gejstlige Foresatte, Provst Gottfriedsen delte hans Syn, viser en Konsistorialskrivelse af 16. Marts 1895 til Provsten, der vel maa have henvendt sig til Konsistoriet om dette Problem. Man kan, hedder det her, være enig med ham i, at den nordslesvigske Gejstlighed maa holde sig fjern fra politisk Agitation uden derfor at fornægte sin Tyskhed. Men fortsættes der - og nu kommer der noget, der tydeligt røber dets Dobbeltstilling som Kirkestyrelse og politisk Organ — der vil dog altid kunne være Undtagelser som nu ved Pastor Jacobsen, og man vil ikke kunne regne med at ændre hans Sindelag. Det maa dog stadig indskærpes ham, at han i første Række er Præst. Da var Kaftan forsaavidt mere konsekvent, selvom man ogsaa hos ham mærker, at han i nogle Aar (1880-85) havde været "Regerings- og Skoleraad“ paa Gottorp og var klar over, at for Staten havde de politiske Hensyn langt større Betydning end de kirkelige. I sin Skildring af de for ham saa stormfulde Aar o. 1900, da der var stærke Kræfter i Gang for at flytte ham fra Slesvig til Holsten (jfr. S. Aarb. 1907. S. 324 f.) fortæller han S. 255, at da han "sidste Gang“ (Aaret nævnes ikke) var paa Visitats i Skærbæk, spurgte han Pastor Jacobsen, der jo overvejende interesserede sig for Politik og Økonomi, om han ikke tænkte paa at nedlægge sit Embede for helt at hellige sig disse Hverv, „et Spørgsmaal der laa nær, da han forvaltede sit Embede paa en højst overfladisk Maade“, medens han „endnu dengang" troede, at Præsten var værdifuld for den prøjsiske Politik, som den da førtes („nach üblichem Verstand“). Svaret blev et Nej og dermed lod Bispen Sagen falde. Men Pastor Ja-

2) Erlebnisse und Beobachtungen (1924). S. 227 - Om Foreningen siger han S. 224. Anm., at den var "reichlich mit Tanz und Alkoholк. 
cobsen beklagede sig over ham til sine Venner, og en af disse, en Landraad „, i en anden Kreds“ (v. Uslar i Aabenraa?) klagede tjenstlig over, at Bispen nu var gaaet saa vidt, at han vilde skaffe en Præst af Vejen, fordi han var "en god Tysker". Skrivelsen naaede helt til Berlin og har næppe været uden Indflydelse paa Planerne om Kaftans Forflyttelse.

Selvom Konsistoriet, som ovenfor nævnt, havde ment, at Pastor Jacobsen maatte have en Undtagelsesstilling, satte hans Færd det øjensynlig mange graa Haar i Hovedet. Den 29. April 1896 paalægger det Provsten, at indhente en Erklæring om "Udstrækningen og Formaalet“ med hans Agitationsrejser i de to sidste Aar. Efter en ved Sagen liggende Tidsskriftartikel af Pastor Jacobsen har Formaalet aabenbart været at skaffe Penge til hans Kreditbank for at imødegaa den "uforsonlige Danskhed“, der hidtil gennem den stedlige Sparekasse havde været „den alt dominerende“. Som det fremgaar af en noget senere Skrivelse til Provsten fra Konsistoriet havde dette ikke været tilfreds med Pastor Jacobsens Erklæring, der savnede „den tilbørlige Aabenhed" (die gebührende Offenheit). En lille Ting viser $f$. $\bullet$., at det allerede dengang ikke stod helt godt til med Kreditbanken. I Sommeren 1895 havde Konsistoriet givet sin Tilladelse til at sælge noget af Præstegaardsjorden til en Byggegrund for Banken, men Præsten havde uden videre ladet Købesummen (1126 Mk.) blive staaende i Kreditbanken. Dette gav Anledning til en Del Skriverier bl. a. en paa Dansk affattet Skrivelse fra de Kirkeældste til Konsistoriet, men først et halvt Aars Tid senere kunde Præsten meddele, at nu var Pengene bleven indsat i "Haderslebener Sparkasse“. Det var ikke sidste Gang de Kirkeældste kom i Konflikt med ham om økonomiske Sager. I 1902 (27/10.) klager de saaledes til Provstisynodeudvalget over, at de ikke kunde faa Regnskabsopgørelsen fra ham for et andet solgt Jordstykke og spørger samtidig om de havde Pligt til at paase, hvorledes Præstegaardsjorden blev forvaltet. Han havde nemlig - aabenbart uden deres Samtykke - udlagt ca. 4 ha. Eng til Fiskedamme. Og et Par Maaneder senere (5/12.) faar Udvalget en beslægtet Sag om Præste- 
gaardsengen, hvor de Kirkeældste rentud erklærer, at de ikke ved, hvad de skal gøre, da et Sagsanlæg mod Præsten jo ikke var saa let.

Øjensynlig havde Konsistoriet ikke været helt tilfreds med Pastor Jacobsens Agitationsrejser. Anderledes saa det paa hans Bestræbelser for at øge de tyske Gudstjenesters Antal. Herom skal der gøres noget nærmere Rede, dels for at vise hvorledes sligt kunde gribes an, dels fordi denne Sag giver et klart Billede saavel af Provst Gottfriedsens Syn paa Pastor Jacobsen som af hans personlige Indstilling overfor Sognets Fører, den danske Mand P. Timmermann.

I sin fortjenstfulde Afhandling om Statskirkens Fortyskning i S. Aarb. 1913 oplyser Redaktør Niels Hansen (S. 191), at efter at Pastor Jacobsen 1839 egenmægtig havde indført 12 tyske Gudstjenester aarligt i Skærbæk, der dog ofte ikke blev afholdt „af Mangel paa Tilhørere“, indførtes der 189715 aarlige tyske Gudstjenester. Det sikkert af Pastor Jacobsen inspirerede Andragende gik denne Gang den sædvanlige tjenstlige Vej gennem Provsten til Konsistoriet i Kiel, men helt saa glat, som da han havde handlet paa egen Haand, gik det nu ikke denne Gang. Fra Provst Gottfriedsen i Nustrup fik han nemlig sit d. 30. Jan. daterede Andragende tilbage med forskellige intrikante Spørgsmaal, som han lod gaa videre til sin højre Haand, den tidligere Gendarm, nu Bankkasserer Lassen. De gik dels ud paa, om Underskrifterne var egenhændige, hvortil Lassen svarer „Ja selvfølgelig“ dog maaske med een Undtagelse, da der var to Mænd af samme Navn i Sognet, dels om hvormange der var i Stand til at følge en dansk Prædiken, hvorom Lassen ikke tør udtale sig. Sagen gaar nu tilbage til Provsten, der dog ikke maa have været helt tilfreds med Svarene. I et med et understreget „sehr vertraulich" mærket Brev sender han nemlig (29/5.) Andragendet til - P. Timmermann, hvis Udtalelse han æsker om de to nysnævnte Spørgsmaal samt om et tredje: Hvormange af Underskriverne der var „danske Undersaatter". Det meget udførlige Svar kom omgaaende d. 2. Juni. Det er skrevet paa Dansk og enhver Grafolog vil af 
dets stive, stejle Haandskrift uvilkaarlig drage den Slutning, at her taler en Mand, der ikke var let at løbe overende. Det lyder ordret:

1) En Deel af Underskrifterne ere mig ubekjendte, men antager at De ere egenhændigt skrevne, i ethvert den største Deel;

2) Af Underskriverne ere:

a. 7 danske Undersaatter,

b. 3 Damer,

c. Pastor Jacobsens Tjenestekarl Iver P. Raun,

d. Postmedhjælper Sørensen, Banevogter Hauster og Kommis Ditlefsen ere allerede flyttede bort fra Sognet.

3) a. En dansk Prædiken med Velsignelse kunde følgende Personer ikke deltage i!

1. Bankkasserer Lassen

2. Banemester Weyl ..

3. Bankkontorist Rabe

4. Gendarm Schüler

5. Kaadner P. Meyhoff

6. Murersvend Paul Hans Petersen

7. Baneforvalter Heningsen

8. Amtsforstander Peters

9. Dreier Robert Laube

b. følgende 8 Navne ere mig ubekjendte, om de ere tilrejsende Haaandværkssvende eller andre Personer, ved jeg ikke, og overhovedet, om de boer her i Sognet: M. Albert, Simonn Pryhas, C. A. Kühl, H. Schiemann, Schmidt, G. W. Stuckert, Georg Bogdahn og H. Jensen.

c. 3 Damer, hvoraf den ene kun forstaar en tysk Prædiken, den anden kun en dansk Prædiken, den tredie baade tysk og dansk Prædiken.

d. 8 Personer ere bortrejste, af de øvrige 70 Personer ere 26 Personer som kun forstaaer en dansk Prædiken".

Selvom Timmermann paa det Tidspunkt endnu var Kirkeældste og Medlem af Provstisynoden, og Provsten saaledes juridisk var berettiget til at æske hans Skøn, virker 
det dog saa ejendommeligt, at en forholdsvis saa højtstaaende, prøjsisk Embedsmand som en Provst henvender sig til Egnens danske Fører og Pastor Jacobsens bitre Modstander, at man uvilkaarlig spørger sig selv, om han trods alt skulde være dansk orienteret. Dette er dog ingenlunde Tilfældet, snarere tværtimod. Som barnefødt i Sognet talte han snart sagt selvfølgeligt godt dansk. Men han var en „renlivet Tysker“, hvilket tilstrækkelig fremgaar af det af afdøde Gaardejer Jens Gram forfattede Tillæg til den af Provsten skrevne officielle "Kirchenchronik". ${ }^{3}$ )

Efter dette synes han saaledes at have været ivrig for at udrydde den Smule Dansk, Reskriptet af 1888 endnu havde levnet i Skolen, altsaa de fire danske Religionstimer, ligesom han fik de Par tyske Eftermiddagsgudstjenester, der med de Kirkeældstes Tilslutning var bleven indført af Hensyn til de sydfra o. 1900 indvandrede Familier, forøget og henlagt til Søndag Formd. (jfr. S. Aarb. 1913. S. 188-89). Og da Provstisynodens Andragende til Konsistoriet om to fattige Timers Danskundervisning een Gang var blevet afslaaet, vilde han ikke gaa med til yderlige Forsøg. Men foruden at være en dygtig Embedsmand, var han en retsindig Mand, der maa have næret en dyb Mistillid til Pastor Jacobsen og i det Hele stod paa en god Fod med den danske Befolkning. Hvad der slog Hovedet paa Sømmet, har dog vel nok været, at han, efter hvad Amtslæge Lausten-Thomsen har meddelt mig, fra Barndommen af har kendt P. Timmermann.

Uanset hvorledes hans Indstilling til Konsistoriet end har været, indførte dette allerede den 18. Juni s. A. de af Præsten ønskede 15 Timer. Besøget maa dog ikke have svaret til Forventningerne, thi smaa to Aar senere udsendte han en Formaning til Tyskerne om at møde op til de tyske Gudstjenester med deres Familie (Flensbg. Avis 1898. Nr. 39). Man forstaar efter dette oprigtig talt ikke, at Konsistoriet i 1906 (28/2) kunde

3) Jeg skylder Pastor Ebbesen i Nustrup megen Tak, fordi han har givet mig Uddrag af dette samt forskellige andre Oplysninger om Provst G. 
meddele Provsten, at de 15 Gudstjenester skulde forøges til 24 nemlig 1. og 3. Søndag i hver Maaned. ${ }^{4}$ )

Men da var Pastor Jacobsen ikke mere Præst i Skærbæk og Aaret efter bogstaveligt talt "over alle Bjerge“.

Det var i Foraaret 1903, at Administrationen - unægtelig noget sent - fik Øjet opladt for Pastor Jacobsens Svindlerier med sin Kreditbank, og efter at Rigsdagsvalget d. 16. Juni 1903 var overstaaet, indledtes Retsforfølgelsen mod ham (jfr. S. Aarb. 1907. S. $395 \mathrm{ff})$. Allerede forinden havde Konsistoriet dog taget Affære. D. 15. Maj s. A. meddelte det nemlig Provsten og gennem ham Kirkeforstanderskabet ${ }^{5}$ ) og den 30. Okt. bad det Provsten om Besked om, hvorledes Forholdene i Skærbæk artede sig samt om Pastor Jacobsens Opførsel; afskedige ham kunde det nemlig ikke, førend den mod ham rejste Sag var sluttet. Vist nogenlunde samtidig med, at de talrige af det offentlige mod ham anlagte Processer var begyndt at løbe (jfr. S. Aarb. 1907. S. 339) besluttede ogsaa Konsistoriet at rejse Sag mod ham, fordi han paa Grund af sin „Drukkenskab og usædelige Vandel, (unsittlicher Lebenswandel) havde gjort sig uværdig til den Agtelse og Anseelse, hans Livsstilling (Beruf) krævede“.

2. August faldt Dommen, der stod paa Afsked (Dienstentlassung) paa Grund af hans Forhold udenfor Tjenesten (ausser dem Amte), ligesom han selv skulde afholde Omkostningerne ved Sagen, der med ægte prøjsisk Grundighed opgaves til 1164 Mk. og $21 \mathrm{Pf}$., der skulde betales inden 8 dage. Og det hjalp ikke, at han appellerede til Kirkeministeriet i Berlin, som i et og alt stadfæstede Dommen. ${ }^{6}$ ) Saaledes endte Pastor Jacobsens 20 aarige Virksomhed som Præst i Skærbæk.

At Regeringen i Slesvig saalænge holdt sin Haand over ham, forklares vel med, at den $i$ v. Köllers Tid $i$ et og alt fulg-

4) Efter Niels Hansens Oplysninger (S. Aarb. 1913. S. 91) sker dette allerede somkring 1900* men somkring 1905 indskrænkes de til de tidligere 15.

${ }^{5}$ ) Det maa have været en Triumf for Timmermann, da han d. 15. Juni paa Dansk saa at sige kvitterede for Modtagelsen!

6) Jfr. Skr. fra Konsistoriet til Provstiudvalget af 1903 15./5., 30/11. samt 1904 18/4. og 1904 25/8., 14/9. og 24/12. 
te den Kurs, der var lagt af den „Den tyske Forening", hvis Formand han var bleven. Men man forstaar oprigtig talt ikke den Mangel paa Samarbejde, der her havde været mellem Regeringen og Konsistoriet i Kiel, der i d. m. delvis saa med større Skepsis paa Foreningen (jfr. S. 178) og maa have været klar over, at alene Pastor Jacobsens menneskelige Skrøbeligheder gjorde ham uværdig til at være Præst.

Et endnu mere grelt Eksempel paa, hvorledes de politiske Myndigheder behandlede de kirkelige, er dog Udstedelsen af Skoleinstruksen af 18. Dec. 1888, der helt fordrev Danskundervisningen fra Folkeskolen. Efter hvad Kaftan fortæller i sine Erindringer, anede han intet om denne „ominøse“ Forordning, som han gentagne Gange kalder den, førend han læste den i Regeringens „Amtsblatt“. At den er udklækket i Berlin og ikke paa Gottorp, viser Overpræsidenten, v. Steinmanns Ytring til ham: „Ich habe es so nicht gewollt“. Men unægtelig havde man der glemt en gammel prøjsisk Instruks fra 1828, der paabød; at slige indgribende Bestemmelser skulde forelægges Generalsuperintendenterne. 